\title{
Interaction and brand experience as a path for brand love: a PLS-SEM marketing application.
}

\author{
Completed Research Paper
}

\author{
Karla Barajas-Portas \\ Universidad Anáhuac México Norte \\ karla.barajas@anahuac.mx
}

\begin{abstract}
Interaction through online social networking sites is one of the most relevant topics nowadays. In the other hand, brand experience has become a powerful for marketers also creating an important bond. Considering both constructs, we propose to analyze the effect of them as a path of the brand love. We analyze the effect of interaction and brand experience on brand love. We conducted a path analysis using PLS-SEM. This paper explores a new way for marketers to improve the engagement with consumers. These interactions between consumers and their brands make stronger the relationship among them.
\end{abstract}

Keywords: Social media, branding, marketing experience, brand love, PLS.

\section{Introduction}

This paper empirically explores the impacts of interaction and brand experiences on brand love. The first part of this paper exposes a literature review about the three constructs we are dealing with. After that we expose the methodology details considering the sample size, the scale used for the study and the statistical method to use.

We conducted a path analysis using partial least squares as the most suitable approach of structural equation modeling for the purpose and characteristics of the study. Finally we present the model and the results of the procedure.

\section{Literature Review and Research Hypotheses}

\subsection{Social media interaction}

Digital evolution and especially social media have changed how consumers and marketers communicate. Peer communication through social media (SM), a new form of consumer socialization, has profound impacts on consumer decision making and thus marketing strategies (Vinerean, Cetina, Dumitrescu, \& Tichindelean, 2013).

Social media websites provide an opportunity for companies to engage and interact with consumers, to be in touch and increase the intimacy of the customer relationship, and in those platforms we can create meaningful relationships. (Mersey, Malthouse, \& Calder, 2010). 
Marketers are now able to reach consumers and interact with them using social media. This is an opportunity to improve the relationship, but it is also a risk. (Chung \& Austria, 2010). We want to demonstrate that a personal relation with brands and products on digital paths, are the optimal way to obtain love of the consumers.

\subsection{Brand Experience}

Brand experience is a construct developed on the last decades, although experiences in marketing was considered previously, there was a topic not researched as a multidimensional construct (Holbrook \& Hirschman, 1981) (Hirschman, 1984) (Gimeno, 1986) (Edell \& Burke, 1987) (Batra \& Ahtola, 1990) (Bedolla P., 2002) (Schmitt, 2005).

For many years, experience considered the sensory stimuli as the producer of a complete brand experience. By human nature, people capture all the information about the environment by the 5 human senses simultaneously, but in marketing not all the brands pay attention on this fact. Martin Lindstrom made an effort to demonstrate that it is very important to considerer all the senses conducting a huge study in order to develop a "sensogram", that is the methodology of measurement of brand sensory (2005). More recently, sensory marketing has expanded to include all five senses, sensory environments, and sensory branding (Hulten, 2008).

Bernd Schmitt had been researching about experiential marketing since 90's, he wrote a practitioner book in which he developed a group of recommendations about how companies has to implement the experience in marketing as a point of differentiation for products (Schmitt, 2005). In the past decade expended a lot of time working with Brakus and Zarantonello and they developed a one of the most accepted scales for the brand experience. ("Brand Experience: What is it? How is it measured? Does it affect loyalty?" 2009).

Brand experience is conceptualized as sensations, feelings, cognitions and behavioral responses evoked by brand-related stimuli that are part of a brand's design and identity, packaging, communications and environments (2009, pág. 52)

\subsection{Brand Love}

Brand love is defined as the degree of passionate emotional attachment a satisfied consumer has for a particular brand and includes passion for a brand, attachment to the brand, positive evaluation of the brans, positive emotions and declarations of love for the brand (Carroll \& Ahuvia, 2006). They found that brand related with hedonic products generate easily stronger relations. For that reason we are considering brands that people declare as their favorite one, no matter the category. Further studies could analyze that relation.

Brand love is important in a marketing strategy context because of its relationship with loyalty and word of mouth. (Bergkvist \& Bech-Larsen, 2010). Considering interaction on social networking sites as a type WOM, we are testing the possible relation establish in prior studies.

\section{Research Method}

The aim of the present study is to test the impact of interaction (SNS) and brand experience on brand love construct. For that purpose we use different scales taken from 
previous studies.

For brand experience we use the scale developed by Brakus, Schmitt \& Zarantonello (2009). This measurement was developed considering a second order AFC. The four factor model includes: sensory, affective, behavioral and intellectual, with 3 items each one. This brand experience scale was used as a predictor of consumer behavior and to profile consumers (Zarantonello \& Schmitt, 2010).

For Interaction we are testing a scale developed for this purpose taking as base the following authors: (Chung \& Austria, 2010) (Mersey, Malthouse, \& Calder, 2010) (Vinerean, Cetina, Dumitrescu, \& Tichindelean, 2013).

In the case of brand love we use the scale developed by Carroll \& Ahuvia. The original scale considered 10 items, we adapted it for our purpose and we reduce it to 6 items, considering recommendations of the work made by Bergkvist \& Bech-Larsen (2010).

Table 1: Construct items

\begin{tabular}{|c|c|c|}
\hline Factor & Code & item \\
\hline \multirow{6}{*}{ Brand love } & $\mathrm{BL}-1$ & This is a wonderful brand \\
\hline & $\mathrm{BL}-2$ & This brand makes me feel good \\
\hline & $\mathrm{BL}-3$ & This brand makes me very happy \\
\hline & $\mathrm{BL}-4$ & I love this brand! \\
\hline & BL-5 & I am passionate about this brand \\
\hline & BL-6 & am very attached to this brand \\
\hline \multirow{10}{*}{ Brand Experience } & BE-S-1 & $\begin{array}{l}\text { This brand makes a strong impression on my visual } \\
\text { sense or other senses. }\end{array}$ \\
\hline & BE-S-3 & This brand appeal to my senses. \\
\hline & BE-A-1 & This brand induces feelings and sentiments. \\
\hline & BE-A-2 & I have strong emotions for this brand. \\
\hline & BE-A-3 & This brand is an emotional brand. \\
\hline & BE-B-1 & $\begin{array}{l}\text { I engage in physical actions and behaviors when I use } \\
\text { this brand. }\end{array}$ \\
\hline & BE-B-2 & This brand results in bodily experiences. \\
\hline & BE-B-3 & This brand is action oriented. \\
\hline & BE-I-1 & $\begin{array}{l}\text { l engage in a lot of thinking when I encounter this } \\
\text { brand. }\end{array}$ \\
\hline & BE-I-2 & This brand make me think. \\
\hline \multirow{8}{*}{ Interaction } & ISM-1 & $\begin{array}{l}\text { think the content shared by this brand on the } \\
\text { socialmedia networks is interesting }\end{array}$ \\
\hline & ISM-2 & $\begin{array}{l}\text { I follow the brand pages in order to obtain recent } \\
\text { information of the brand/products }\end{array}$ \\
\hline & ISM-3 & $\begin{array}{l}\text { I visit the brand page on social media networks } \\
\text { regulary }\end{array}$ \\
\hline & ISM-4 & $\begin{array}{l}\text { I am interested on having a digital relationship with } \\
\text { this brand }\end{array}$ \\
\hline & ISM-5 & This is brand with which I can talk (chat) \\
\hline & ISM-6 & I follow this brand every day on facebook \\
\hline & ISM-7 & I follow this brand every day on twitter \\
\hline & ISM-8 & This is a brand who listen to me \\
\hline
\end{tabular}


The survey consists of 30 questions, 6 of them were demographic, 6 related to feelings and emotions to favorite brand, the rest item related to brand experience and interaction via SNS. We use a seven-point Likert scale (1="completely disagree", and 7="completely agree") for the 20 items provided in the Table 1 .

The information was collected from respondents by a survey applied between January and May 2014. We used the convenience sampling technique which implies a non-probability sampling. We ask to 95 real consumers to answer the questionnaire. The sample was represented by undergraduate students of the Universidad Anahuac Mexico Norte, $48 \%$ male and $52 \%$ female. Respondents ranged in age from 18 to 24 . We found that all of them use at least Facebook, 72\% use also twitter, 54\% uses other SNS (foursquare, LinkedIn, Instagram, vine). $86 \%$ of the respondents use SNS several times a day, $67.3 \%$ use SNS once each day, $3.4 \%$ few times a week.

We ask for their favorite brand and if they used to buy it and if they interact with it on digital platforms. First we make questions about the consumption and the feeling for the brand. All the questions about interaction are according with the brand that the user designed as favorite one. We are not researching about a brand or a category brand, we are trying to understand which is the bond and how does it impact brand love.

\section{Results}

Smart PLS structural modeling was employed for testing the model. The results of the measurement and the path are show on the figure 1 . The R2 is 0.302 for brand love and 0.329 for brand experience. This means that interaction and brand experience moderately explain $30 \%$ and $32.9 \%$ of the endogenous latent variables.

The inner model suggests that interaction has the strongest effect on brand experience (0.574) followed by interaction on brand love (0.314) and brand experience on brand love (0.306). The hypothesized path relationship between Interaction and brand experience on brand love is statistically significant. Thus we can conclude that interaction and brand experience are both moderately strong predictors of brand love; and interaction is moderately strong predictor of brand experiences.

The outer model loading are acceptable, all of them are greater than 0.5. The AVE for brand experience (0.501), brand love (0.567) and interaction (0.537). (Table 2).

Table 2: Construct items Results for outer model 


\begin{tabular}{|c|c|c|c|c|c|c|}
\hline Factor & Code & item & $\begin{array}{l}\text { Factor } \\
\text { Loading } \\
\end{array}$ & AVE & \begin{tabular}{|l|} 
Composite \\
reliability \\
\end{tabular} & $\begin{array}{c}\text { Reliability } \\
(\alpha)\end{array}$ \\
\hline \multirow{6}{*}{ Brand love } & $\mathrm{BL}-1$ & This is a wonderful brand & 0.502 & \multirow{6}{*}{0.567} & \multirow{6}{*}{0.884} & \multirow{6}{*}{0.843} \\
\hline & $\mathrm{BL}-2$ & This brand makes me feel good & 0.688 & & & \\
\hline & $\mathrm{BL}-3$ & This brand makes me very happy & 0.855 & & & \\
\hline & BL-4 & I love this brand! & 0.878 & & & \\
\hline & BL-5 & I am passionate about this brand & 0.783 & & & \\
\hline & $\mathrm{BL}-6$ & I am very attached to this brand & 0.752 & & & \\
\hline \multirow{10}{*}{ Brand Experience } & BE-S-1 & $\begin{array}{l}\text { This brand makes a strong impression on my visual } \\
\text { sense or other senses. }\end{array}$ & 0.551 & \multirow{10}{*}{0.501} & \multirow{10}{*}{0.909} & \multirow{10}{*}{0.888} \\
\hline & BE-S-3 & This brand appeal to my senses. & 0.610 & & & \\
\hline & BE-A-1 & This brand induces feelings and sentiments. & 0.783 & & & \\
\hline & $B E-A-2$ & I have strong emotions for this brand. & 0.791 & & & \\
\hline & BE-A-3 & This brand is an emotional brand. & 0.647 & & & \\
\hline & BE-B-1 & $\begin{array}{l}\text { I engage in physical actions and behaviors when I use } \\
\text { this brand. }\end{array}$ & 0.745 & & & \\
\hline & BE-B-2 & This brand results in bodily experiences. & 0.748 & & & \\
\hline & BE-B-3 & This brand is action oriented. & 0.766 & & & \\
\hline & $\mathrm{BE}-\mathrm{I}-1$ & $\begin{array}{l}\text { I engage in a lot of thinking when I encounter this } \\
\text { brand. }\end{array}$ & 0.699 & & & \\
\hline & $B E-1-2$ & This brand make me think. & 0.699 & & & \\
\hline \multirow{8}{*}{ Interaction } & ISM-1 & $\begin{array}{l}\text { I think the content shared by this brand on the } \\
\text { socialmedia networks is interesting }\end{array}$ & 0.802 & \multirow{8}{*}{0.537} & \multirow{8}{*}{0.901} & \multirow{8}{*}{0.872} \\
\hline & ISM-2 & $\begin{array}{l}\text { I follow the brand pages in order to obtain recent } \\
\text { information of the brand/products }\end{array}$ & 0.809 & & & \\
\hline & ISM-3 & $\begin{array}{l}\text { I visit the brand page on social media networks } \\
\text { regulary }\end{array}$ & 0.747 & & & \\
\hline & ISM-4 & $\begin{array}{l}\text { I am interested on having a digital relationship with } \\
\text { this brand }\end{array}$ & 0.832 & & & \\
\hline & ISM-5 & This is brand with which I can talk (chat) & 0.699 & & & \\
\hline & ISM-6 & I follow this brand every day on facebook & 0.806 & & & \\
\hline & ISM-7 & I follow this brand every day on twitter & 0.543 & & & \\
\hline & ISM-8 & This is a brand who listen to me & 0.563 & & & \\
\hline
\end{tabular}




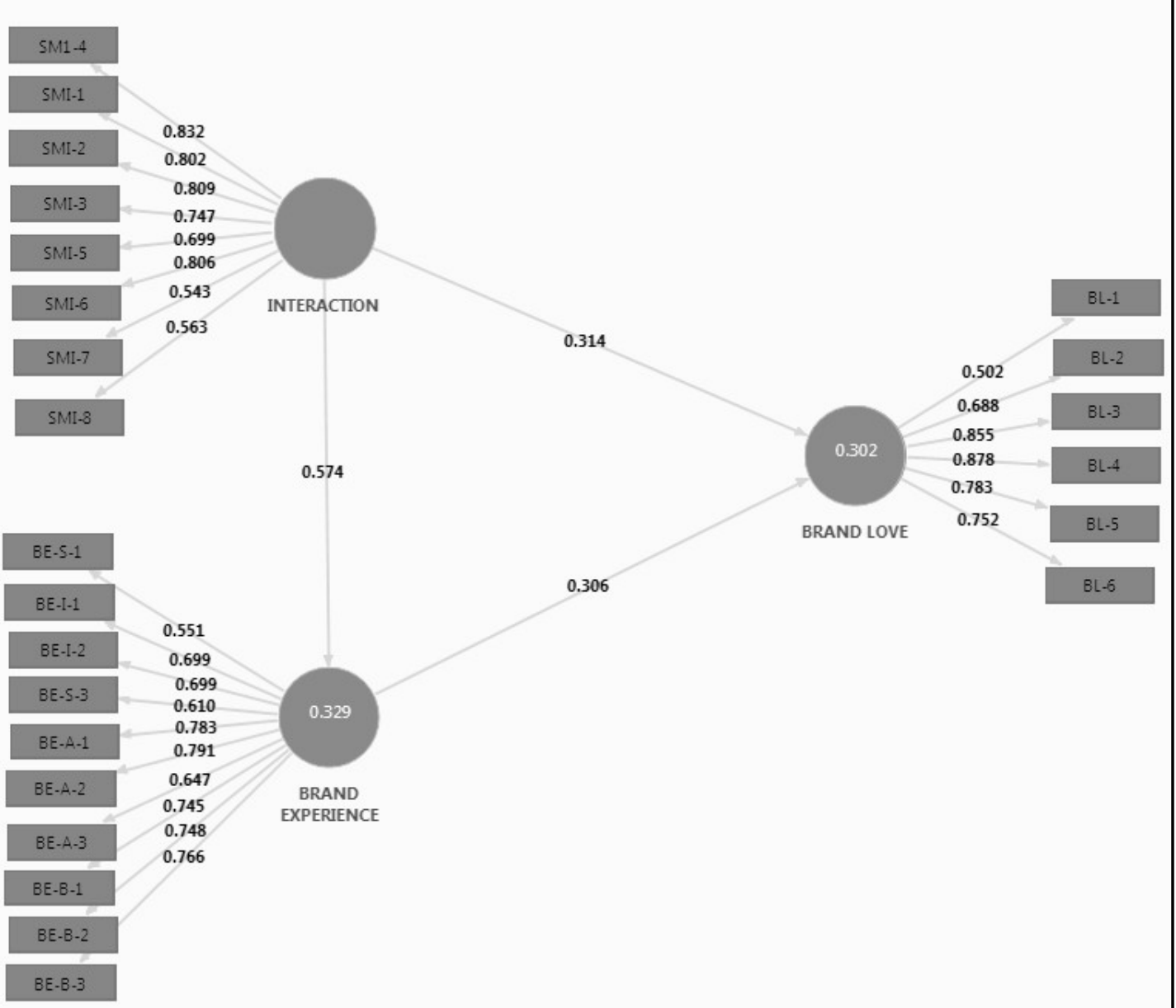

Figure 1: Brand love path model

\section{Discussion}

According with the statistical model, we can conclude that the interaction on social networking sites and the brand experiences generated by marketing strategies are predictors of brand love. Previous literature assumes that brand love results on loyalty, but we do not test this relationship on this paper, but it could be a future research to explore that impact.

For effective and strong relationship between brands and consumers, it should be considered how to participate in social media and how provide experiences in the 4 paths: Sensual, affective, behavioral and intellectual.

The relevance of this research is taking the first step for testing the impact of digital interaction and experiences on the desired brand love. The aim is giving new marketing strategies for the theoretical and empirical support which has the importance of these factors for consumers. In this way, companies must pay more attention to their actions on Social Media and control agents that inherently exist in products and optimizing their use to improve your brand image actions and generate sustainable competitive advantage in time. The natural human processes as socialization, interaction and experiences are the first link in the production of emotions and remain on consumers mind and heart for longer than the images of traditional communication. 


\section{References}

Batra, R., \& Ahtola, O. T. (1990, abril). Measuring the hedonic and utilitarian sources of consumer attitudes. Marketing Letters, 2(2), 159-170.

Bedolla P., D. (2002). Tesis Doctoral: "Diseño Sensorial: Las nuevas pautas para la innovación, especialización y personalización del producto".

Bergkvist, L., \& Bech-Larsen, T. (2010). Two studies of consequences and actionable antecedents of brand love. Brand Management, 17(7), 504-518.

Brakus, J., Schmitt, B., \& Zarantonello, L. (2009). "Brand Experience:What is it? How is it measured? Does it affect loyalty?". Journal of Marketing, 52-68.

Carroll, B. A., \& Ahuvia, A. C. (2006). Some antecedents and outcomes of brand love. Marketing letters, 79-89.

Chung, C., \& Austria, K. (2010). Social Media Gratification and Attitude towards Social Media Marketing Messages: A study of the effect of Social Media Marketing Messages on Online Shopping Value. Proceedings of the Northeast Bussiness \& Economics Association, (pp. 581-586).

Edell, J., \& Burke, M. (1987). "The power of feelings in understanding advertising effects". Journal of Consumer Research, 14, 421-433.

Gimeno, J. (1986). La educación de los sentidos. Madrid: Santillana.

Hirschman, E. (1984). Experience seeking: a subjectivist perspective of consumption. Journal of Business Research, 115-136.

Holbrook, M., \& Hirschman, E. (1981, sept). "The experiential aspects of consumption: Consumer Fantasies, feelings and Fun". Journal of Consumer ResearcH, 9, 132-140.

Hulten, B. (2008). The Supreme Sensory Experience. In ESOMAR (Ed.), ESOMAR Congress 2008: Frontiers in research. Montreal.

Lindstrom, M. (2005). Brand sense: Build Powerful Brands through Touch, Taste, Smell, Sight and Sound. New York, USA: Free Press.

Mersey, R. D., Malthouse, E. C., \& Calder, B. J. (2010). Engagement with online media. Journal of Media Business Studies, 7(2), 39-56.

Schmitt, B. (2005). Experiential Marketing. Barcelona: Deusto.

Vinerean, S., Cetina, J., Dumitrescu, L., \& Tichindelean, M. (2013). "The effects of social media marketing on online consumer behavior". International Journal of Business and Management, 66-79.

Zarantonello, L., \& Schmitt, B. H. (2010). Using the brand experience scale to profile consumers and predict consumer behaviour. Journal of Brand Management, 17, 532540. 